\title{
APPLICATION OF ORDINANCE N³10-2009-MDJM, AND NOISE POLLUTION FROM THE VEHICLE FLEET IN THE DISTRICT OF JESÚS MARÍA - 2020
}

Maria Veliz Garagatti

Federico Villarreal National University, (Peru).

E-mail:mveliz@unfv.edu.pe

ORCID: https://orcid.org/0000-0002-8133-1711

Vicenta Tafur Anzualdo

Graduate University School - EUPG - Federico Villarreal National University, (Peru).

E-mail: itafur@unfv.edu.pe

ORCID: https://orcid.org/0000-0002-1888-7848

Susana Irene Davila Fernandez

Ricardo Palma University, (Peru).

E-mail: susana.davila@urp.edu.pe

ORCID: https://orcid.org/0000-0002-6949-1317

Doris Esenarro Vargas

Federico Villarreal National University, (Peru).

Ricardo Palma University, (Peru).

E-mail: desenarro@unfv.edu.pe

ORCID: https://orcid.org/0000-0002-3942-7832

\section{Citación sugerida:}

Garagatti, M. V., Anzualdo, V. T., Davila, S. I., y Vargas, D. E. (2022). Application of ordinance ${ }^{\circ}$ 310-2009-mdjm, and noise pollution from the vehicle fleet in the district of Jesús María - 2020. 3C Tecnología. Glosas de innovación aplicadas a la pyme, Edición Especial, (febrero 2022), 47-63. https://doi. org/10.17993/3ctecno.2022.specialissue9.47-63 


\section{ABSTRACT}

The present research work analyzes the noise pollution of the automobile fleet in the District of Jesús María located in Lima - Perú. The general objective was "To determine the incidence of the application of Ordinance $N^{\circ} 310$ - 2009-MDJM. in the noise pollution of the vehicle fleet in the district of Jesús María, 2020" the type of research is applied; descriptive and explanatory level and non-experimental design. The population object of study was constituted by the inhabitants of the district and the floating population, considering a non-probabilistic sample of 210 people. The instruments used were: measurements of sound pressure in fixed stations, counting of public and private vehicles in the time of measurement of good pressure, and a questionnaire that was validated by expert judges, the same one that constituted 32 items of the scale of Likert. The results found in the sound pressure measurements exceeded the maximum sustainability of the analyzed Ordinance, showing noise pollution. The statistical test used was the Spearman correlation coefficient, determining that there are differences in noise pollution at the stations and not at the timetables; that public and private vehicles increase sound pressure measurements under different conditions; concluding that: "The application of Ordinance No 310-2009-MDJM significantly affects noise pollution in the vehicle fleet in the district of Jesús María, 2020".

\section{KEYWORDS}

Noise Pollution, Vehicle fleet, Ordinance, Public vehicles, Private vehicles. 


\section{INTRODUCTION}

When we think of environmental pollution, we think of it as strange elements that alter the conditions of natural development in space. Generally, it is a consequence of the participation of human beings trying to improve their living conditions; however, if the limits that allow maintaining natural balances are exceeded, these actions considered as beneficial become detrimental to the development of living beings, and that is when pollution in all its aspects appears (Alvarado et al., 2020).

One of them is noise pollution, recognized as a polluting agent in the Environmental Congress organized by the United Nations in Stockholm in 1972 and identified for generating unwanted sounds because they lack harmony and are called noise, or is sharper than living beings can withstand without being damaged; Moreover, it is punctual pollution, which does not generate waste and has the particularity of being easy to adapt in individuals, in such a way that it decreases the sensitivity of those who are in contact with it, that is why scholars of this pollution, among others, consider the influence in addition to physical parameters, other subjective parameters to describe it, so it is inconvenient to clearly explain to the citizen that there is a problem called noise, which is affecting their physical, mental health, and their social quality (Alomoto, 2018).

Several human actions generate this contamination; one of them is the vehicle fleet in urban public spaces, especially where vehicles are old and technical revisions are not a priority, there is no adequate organization of vehicular traffic, and urban downtown areas begin to concentrate their activities both public and private in small spaces which generate a high concentration of citizens who inhabit these spaces and live with the floating population that is developing their work activities, education, visits to health centers among others and need means of transportation to mobilize.

The above mentioned happens in the district of Jesus Maria, a very central area within the capital of Peru, Lima; so, we wanted to know if the district authorities were looking for solutions to this problem, considering that they have the Ordinance No. 310-2009- MDJM, a document which establishes the maximum allowable limits for the generation of noise nuisance and regulates the policies of prevention and noise control to educate the neighbors about this pollution (AMBIO, 2018). 
Environmental pollution is an alteration of the natural environment generated by foreign elements that cause undesirable changes in the spaces where they occur, which in many cases generate disease in humans; these alterations can be of natural origin or generated by the activities carried out by man. One of these contaminations is called noise pollution, produced by waves that move in space which generate sounds perceived by living beings; in the case of man, he can feel pleasant sounds that can favor his emotions, but there are also unpleasant sounds that can affect his physical, psychological and social health. Noise pollution is generated by different causes; some of the most important are those produced by the vehicle fleet, that is, by the circulation of numerous vehicles that travel through the streets and avenues of a city, which is why it is called urban noise pollution (CSU).

The CSU is increasing exponentially in the big cities of the world; recent studies found that Guangzhou in China has the highest noise pollution; this information corresponds to the measurement made by the global index of hearing, which was created by the founders of the digital hearing application Mimi Hearing Technologies GmbH, they analyzed the results of the hearing tests of 200000 of its users (Amable et al., 2017).

\section{METHOD}

\subsection{TYPE OF RESEARCH}

It is applied; this base is based on the technological findings of basic research, linking theory, and reality (Reyes et al., 2021).

Scientific theories are considered concerning the deterioration of the urban environment due to the excess noise generated by the automobile fleet.

\subsection{LOCATION OF THE STUDY AREA}

The district of Jesús María is one of the 43 districts that are part of the province of Lima located in the Department of Lima. It is bordered on the north by Breña and Cercado, on the west by Pueblo Libre, on the south by Magdalena and San Isidro, and on the east by Lince and Crecado (Bizkaia, 2018). 
Table 1. Number of inhabitants of the district of Jesús María.

\begin{tabular}{|c|c|}
\hline TOTAL & DENSITY \\
\hline 71589 hab. & 17897,3 hab/km2 \\
\hline
\end{tabular}

Source: own elaboration.

\section{RESULTS}

\subsection{SOUND PRESSURE MEASUREMENT}

Table 2. Sound pressure measurements at seven stations. Factor: LAeqT.

\begin{tabular}{|c|c|c|c|c|c|c|}
\hline \multirow{2}{*}{ Station } & \multicolumn{2}{|c|}{ UTM Coordenatess } & \multicolumn{3}{|c|}{$\mathrm{L}_{\text {AeqT } 10 \mathrm{~min}}(\mathrm{dBA})$} & \multirow{2}{*}{$\begin{array}{c}\text { Average } \\
\text { (dB) }\end{array}$} \\
\hline & East & South & 07:00-09:00 & 14:00-16:00 & 19:00-21:00 & \\
\hline E01 & 277716 & 8664258 & 71,3 & 69,9 & 71,8 & 71,0 \\
\hline E02 & 277687 & 8663750 & 75,9 & 75,7 & 72,0 & 74,5 \\
\hline E03 & 277284 & 8663443 & 65,7 & 70,3 & 69,8 & 68,6 \\
\hline E04 & 276831 & 8662929 & 66,6 & 64,6 & 65,1 & 65,4 \\
\hline E05 & 276496 & 8662269 & 72,6 & 73,0 & 71,1 & 73,9 \\
\hline E06 & 276012 & 8662589 & 73,5 & 71,0 & 68,3 & 70,9 \\
\hline E07 & 275538 & 8662897 & 70,9 & 75,1 & 68,9 & 71,6 \\
\hline
\end{tabular}

Source: own elaboration.

Table 2 presents the sound pressure measurements taken at the seven work stations, with the highest figures found at E02 in the morning and afternoon hours with 75.9 and 75.7 $\mathrm{dB}$ respectively, and the lowest sound pressure figures at E04, in the afternoon and twilight hours with 64.6 and $65.1 \mathrm{~dB}$ respectively, which are reflected in the average measurements. It is noted that all sound pressure measurements are more significant than $60 \mathrm{~dB}$. 
Table 3. Tests of inter-subject effects.

\begin{tabular}{|c|c|c|c|c|c|}
\hline \multicolumn{6}{|c|}{ Dependent variable: Sound pressure } \\
\hline Origin & $\begin{array}{l}\text { Type III sum of } \\
\text { squares }\end{array}$ & gl & Media cuadrática & $\mathbf{F}$ & Sig. \\
\hline Modelo corregido & $162,820^{a}$ & 8 & 20,353 & 4,910 & ,007 \\
\hline Intersección & 104742,172 & 1 & 104742,172 & 25270,490 &, 000 \\
\hline Estaciones & 150,505 & 6 & 25,084 & 6,052 &, 004 \\
\hline Horarios & 12,315 & 2 & 6,158 & 1,486 & ,265 \\
\hline Error & 49,738 & 12 & 4,145 & & \\
\hline Total & 104954,730 & 21 & & & \\
\hline Total, corregido & 212,558 & 20 & & & \\
\hline
\end{tabular}

Source: own elaboration.

Table 3 shows the sources of variation, sums of squares, degrees of freedom, root mean squares, F-statistics, and critical levels associated with the three effects present in a twofactor model (Alcántara- Malca \& Esenarro, 2018).

The corrected model row refers to all model effects taken together (2-factor, interaction, and intercept or constant effect). The P-value $0.007<0.05$ tells us that the model explains a significant part of the variation observed in the Dependent Variable sound pressure. A coefficient of determination $\mathrm{R} 2=0.766(162,820 / 212,558)$ indicates that the 2 effects included in the model (season and schedule) are explained with the adjusted coefficient of determination $61 \%$ of the variance Dependent Variable sound pressure (Delgadillo \& Pérez, 2017).

The intersection is the constant of the model. The two rows are personal effects of the two factors: season and schedule. The significance levels indicate the mean sound pressure of the groups defined by the variable stations differs $(0.004<0.05)$ while the groups defined by the irregular schedule have non-significant mean times (0.265 > 0.05) (Figueroa et al., 2018).

The error row is related to the source of error variation or residual. The root means square of the error (4.145 is a divisor of each F-ratio), an unbiased estimator of the variance of the populations studied (assumes all equal). The corrected Sum of Squared Total captures the total variance of each effect plus the error variance. 


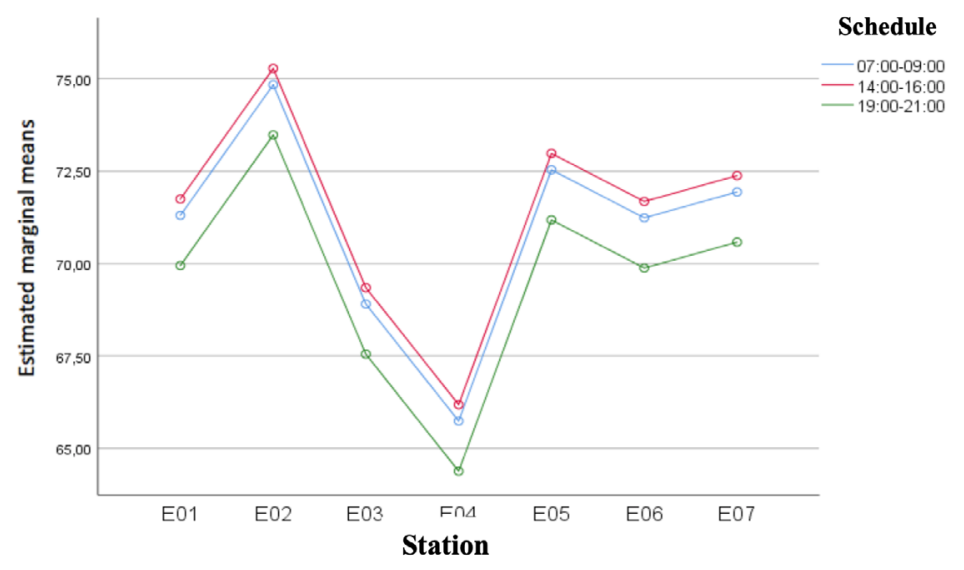

Figure 1. Profile plot results.

Source: own elaboration.

Figure 1 shows the sound pressure averages calculated in each subgroup due to combining each level of the variable stations with each level of the erratic schedule.

\subsection{ENVIRONMENTAL NOISE MAPS}

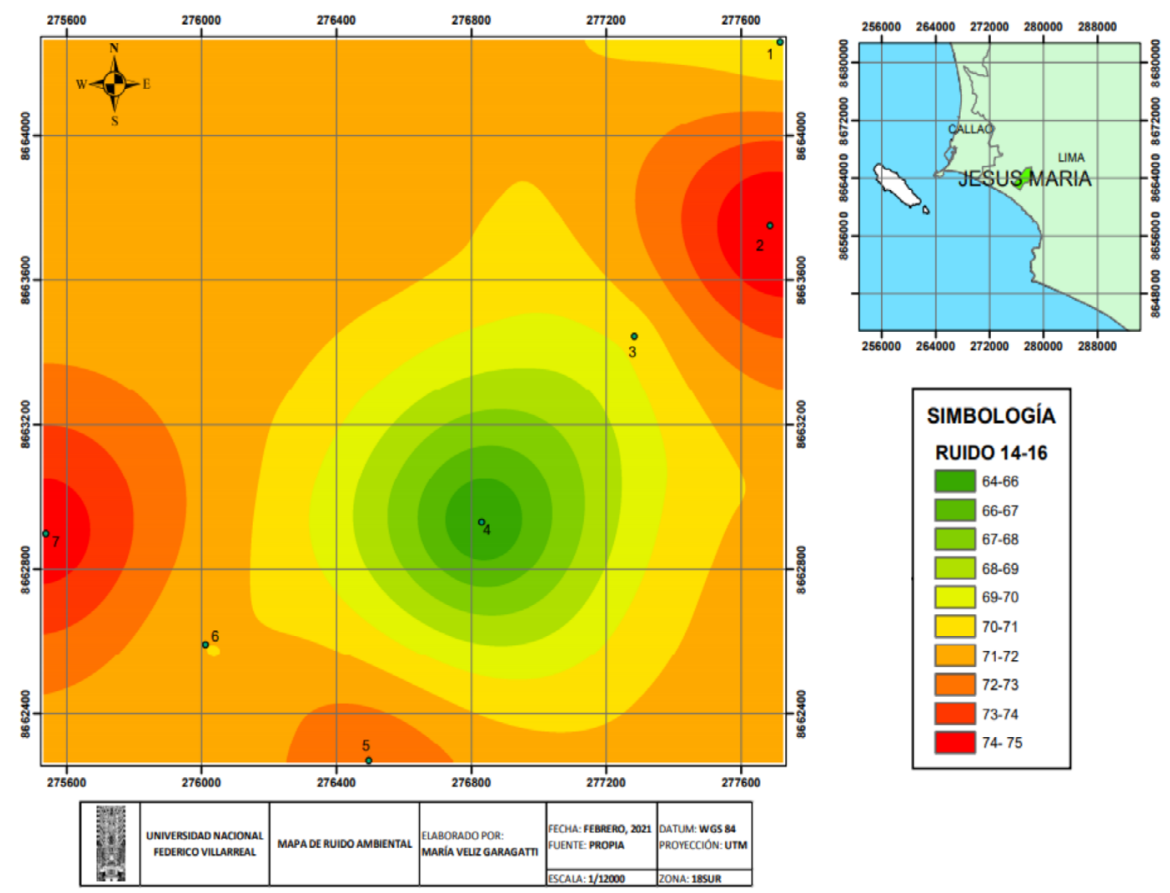

Figure 2. Noise map.

Source: own elaboration. 
The afternoon ambient noise map, Figure 1, has been taken because, making use of the statistical results of the profile graph, Figure 3, indicating the estimated marginal sound pressure measurements, which show that in the afternoon hours, the highest sound pressure measurements are presented. In this map, the two most affected stations, E02 and E07, are shown, expressed in the intense red color that represent the figures of $75.9 \mathrm{~dB}$ and $75.1 \mathrm{~dB}$, respectively; another essential point is E05, where a dark orange color can also be seen that expresses a vital sound pressure figure, $73.0 \mathrm{~dB}$; E06 with $71.1 \mathrm{~dB}$, where the orange color is lower, followed by E01, E03, and E04, with 69.9, 70.3, 64.6, which show even lower orange colors up to the green, indicating lower figures. The morning and twilight Ambient Noise maps (Gray, 2017).

\subsection{METEOROLOGICAL CONDITIONS ANALYSIS}

The monitoring of the meteorological conditions was obtained from the three sampling days, February 12, 18, and 25, 2020, from which the averages of the meteorological conditions have been received by using the measurement hours. In addition, information was obtained from the SENAMHI Mars Field Meteorological Station.

Table 4. Meteorological conditions in the study area.

\begin{tabular}{|c|c|c|c|c|}
\hline PARAMETER & 12 FEB & 18 FEB & 25 FEB & AVERAGE \\
\hline Ambient Temperature $\left({ }^{\circ} \mathrm{C}\right)$ & 22,9 & 25,7 & 22,3 & 23,6 \\
\hline Relative Humidity $(\%)$ & 84 & 72 & 83 & 80 \\
\hline Wind speed $(\mathrm{m} / \mathrm{s})$ & 2,5 & 2,9 & 2,6 & 2,6 \\
\hline
\end{tabular}

\section{Source: own elaboration.}

The figures in Table 4 show temperatures ranging from 22.3 to 25.7 degrees Celsius, with an average of $23.6{ }^{\circ} \mathrm{C}$; relative humidity measurements were also taken in percentages ranging from 72 to 84 percent, with an average of $80 \%$; wind speed was also measured, with an average of 2.5 to 2.9 meters per second, with an average of $2.6 \mathrm{~m} / \mathrm{s}$ (González, 2019). 


\subsection{PROFILE GRAPH RESULTS}



Figure 3. Estimated marginal averages of vehicle flows.

Source: own elaboration.

Figure 3 shows the vehicle flow averages calculated in each subgroup due to combining each level of the variable stations with each level of the erratic schedule.

\subsection{PUBLIC AND PRIVATE VEHICLE FLEET CONSIDERING VEHICLES TYPE.}

We have considered analyzing the flow of public and private vehicles separately. General cars correspond to the light and dark red colors for each sampling station, and private cars conform to the green variants (Hidalgo, 2019).

Table 5. Public and private vehicles per station.

\begin{tabular}{|c|c|c|}
\hline STATION & \% PUBLIC VEHICLES & \% PRIVATE VEHICLES \\
\hline E01 & 55 & 45 \\
\hline E02 & 55 & 45 \\
\hline E03 & 40 & 60 \\
\hline E04 & 36 & 64 \\
\hline E05 & 42 & 58 \\
\hline E06 & 38 & 62 \\
\hline E07 & 30 & 70 \\
\hline
\end{tabular}

Source: own elaboration. 


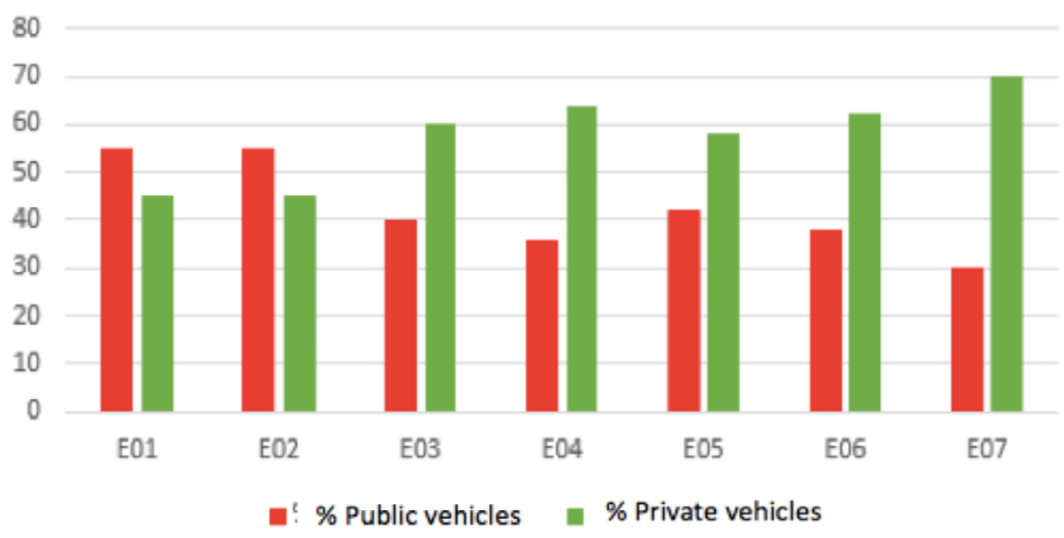

Figure 4. Average percentages of public and private vehicles per station.

Source: own elaboration.

Table 5 and Figure 4 present the averages in the percentage of public and private vehicles to determine the ratio of presence of each of them in each station, and we found the following: in stations E01 and E02, there was a more significant presence of public vehicles in $10 \%$ more than private vehicles, while in E03, E04, and E06 there is a more substantial presence of personal vehicles in a difference of between $20 \%$ to $28 \%$ more than public vehicles, in E05 there is a difference of only $16 \%$ between private and public vehicles, which indicates that both types of vehicles are essential in that station and in the case of E07 the difference is more significant for personal vehicles with $40 \%$ more than public vehicles (Mamani, 2017).

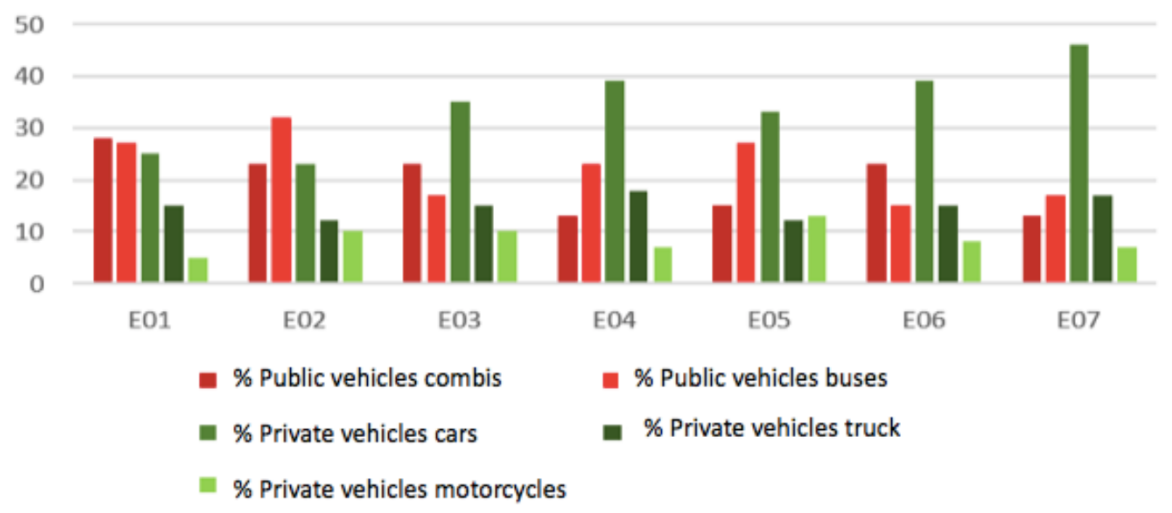

Figure 5. Types of public and private vehicles by station.

Source: own elaboration. 
Figure 5 shows that E01 and E02 have more public vehicles, with both vans and buses in fairly close numbers; the differences do not reach $10 \%$ and are therefore not relevant. In the case of E03, E04, E06, private vehicles are predominant and have similar results in the arrangement of the different types of means of transport. At the same time, E05 presents figures of private cars with vehicles, vans, and motorcycles with representative statistics and the influence of public vehicles that were also present and with significant figures. In E07, there is a high presence of private cars with a relatively representative number of vehicles (46\%) (MDJM, 2019).

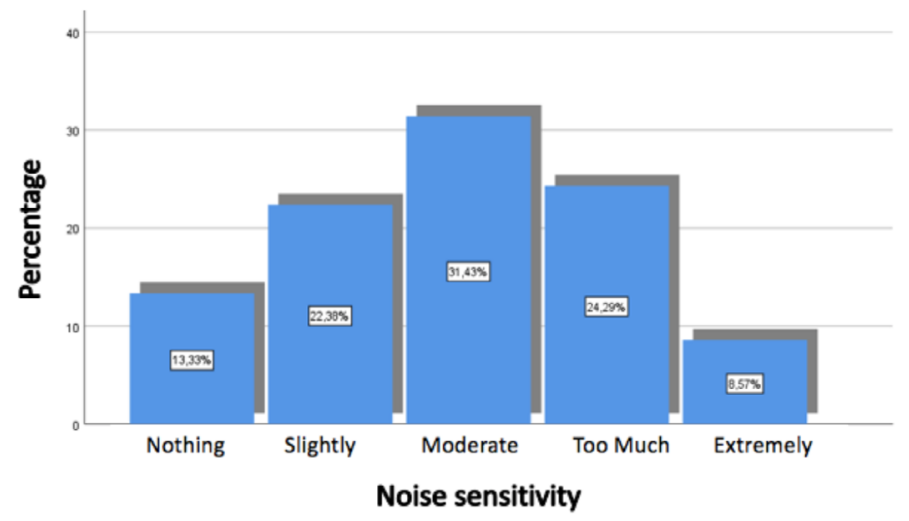

Figure 6. Sensitivity to noise.

Source: own elaboration.

The sensitivity to noise indicated in Figure 6 has been expressed with $31.43 \%$ as moderate, $24.29 \%$ as too sensitive, $22.38 \%$ as slightly sensitive; the last two indicators do not reach 15\% each, so they are not considered relevant (Municipalidad de Jesus María, 2021).

\section{DISCUSSIONS}

The sound pressure meter measurements at the seven stations are significant since P-value $0.007<0.05$ indicates that the null hypothesis is rejected, and the alternative view is accepted. It is concluded that the sound pressure is not the same for all stations. To know where the difference is, we proceeded to a Tukey test, where it can be observed that stations E01 and E06 do not differ in any case since P-value is more significant than 0.05, on the other hand, in stations: E02 differ significantly with E03 and E04; E03 differ significantly with E02; E04 differ significantly with E02, E05, and E07; and E05 and E07 differ significantly E04 (Ocas, 2018). 
The aforementioned results are expressed in Figure 2, where the results of the Profile graph are shown, in which we can find that E02 is the one that presents the highest sound pressure of all the sampled stations and can be seen in average numbers in Table 4 which indicates the figure of $74.5 \mathrm{~dB}$; which compared to E04, reviewing the same tables and figure, shows that it is the station with the lowest figures, with $65.4 \mathrm{~dB}$ of sound pressure and in the case of E05 and E07, intermediate figures of good pressure are presented with $73.9 \mathrm{~dB}$ and $71.6 \mathrm{~dB}$ on average, respectively. The proper pressure measurements can be seen with greater representativeness by observing them in the noise map, Figure 3, which offers us an essential geographic appreciation in the space of the analysis of the measurement nuclei and the dispersion that noise produces spatially, generating more deterioration in the area where it is made. We must note that the barriers of the environments that can reduce the strength of the noise have not been considered, although the measurement stations of this work have vast spaces in which the barriers are distant. It is important to note that all the sound pressure figures obtained in this work are above $60 \mathrm{~dB}$, considered the maximum present in any urban public space, as indicated by the Ordinances of different districts of Lima and other districts cities in Peru. Similar results are found in the works developed; who suggests that in the town of Chimbote, in José Gálvez Avenue, the area with the most traffic, Sound Pressure figures were obtained above $60 \mathrm{~dB}$, considered as maximum in the Municipal Ordinance of his district; also in Iquitos in the center of the city was measured up to $84.24 \mathrm{~dB}$ in the town of Cajamarca in its two downtown avenues Av. Hoyos Rubio and Jr. Manuel Seoane exceeded figures of 100dB (Figueroa et al., 2018).

If we analyze works carried out in Lima, in the campus of the Catholic University of Peru was measured above $70 \mathrm{~dB}$. Therefore, it is considered that the sound pressure measurements obtained in this research work, as in those carried out in all the results presented as background, the excellent pressure figures exceeded $60 \mathrm{~dB}$ for urban public spaces in daytime hours (EFE, 2018).

The measurements of vehicle flow in the seven stations are significant since P-value 0.012 $<0.05$ also suggests we reject the null hypothesis and accept the alternative view. And we conclude that the vehicle flow is not the same for all stations. To locate the difference, we proceeded to a Tukey test, where it can be observed that stations E01, E02, E03, and E05 do not differ in any case since P-value is more significant than 0.05 , on the other hand in 
stations: E04 differs significantly with E06 and E07; in E06 differs significantly E04; in E07 differs significantly with E04 (Ordenanza Nº1965, 2016).

Let's look at the profile graph, where the estimated marginal averages of vehicle flow are presented, Figure 4. We find that: the similarities between E01, E02, E03, and E05 is expressed by the vehicle count in 10 minutes which are in the range of 500 - 550 units, while E06 and E07 had a range between 650 - 700 vehicles in 10 minutes count, the highest figures in our work; finally, E04 presented the range between 300-350 units in 10 minutes. In this analysis, we found that not always the highest sound pressure figure is shown in the station where more vehicles are transiting through a station, as is the case of E02, which has the highest sound pressure figure ( $75 \mathrm{~dB}$ average); however, it was found that it is not the most significant number of cars circulating in that space (500-550. Public vehicles in E02 stop in any room to pick up passengers, creating vehicular congestion and not allowing the flow of the vehicle fleet. In addition, E02 is a Special Protection station due to the location of the Rebagliati Hospital; therefore, its maximum allowed level is $50 \mathrm{~dB}$, and an excess of $21.6 \mathrm{~dB}$ was found (Table 10).

The study of noise pollution in the city of Tarapoto, where she indicates that the most circulating vehicle is the motorcycle cart, which is a means of public transport and is who has generated a relatively high sound pressure exceeding by $20 \mathrm{~dB}$ to $27 \mathrm{~dB}$ more than the noise quality standards in the commercial area; also Cerna, 2015 who indicates among other points that, the high noise level is due to the presence of public vehicles in the study conducted on Av. Universitaria in the city of Lima in 2014 (Delgadillo \& Pérez, 2017), indicates that the highest sound pressure levels are due to motorcycle cabs, who notably raised the sound pressure figures in the area of San Juan de Lurigancho- Lima; in the case of E02 in this work, it was primarily observed buses and combis significantly deteriorated by the excess of years of service that they present. Therefore, a public vehicle fleet that is inadequate or in poor condition and poor organization in the transit system can generate significant noise pollution (Zeballos, 2019).

If we analyze the E07, also of Special Protection due to the location of the Military Hospital, there were also high sound pressure figures with an average of $71.6 \mathrm{~dB}$, in this case exceeding 21. In this case, $21.6 \mathrm{~dB}$ exceeded the maximum allowed, which is $50 \mathrm{~dB}$, 
due to the large influx of private vehicles, since in this station, between 650-700 cars were measured in 10 minutes of counting. Also, the poor management of the traffic system generates an inadequate movement of vehicles entering from Brazil Avenue to Faustino Sanchez Carrion Avenue, making a semicircular movement causing a traffic jam, which produces the high sound pressure level in this station (Rosales, 2017).

In the case of E05, where the second-highest average sound pressure level was measured $(73.9 \mathrm{~dB})$, we found a similar presence of both public (42\% average) and private $(58 \%$ average) vehicles, which also generates significant traffic congestion in addition to the increased company of motorcycles by $13 \%$, the highest in the entire sampling area, which contributed to develop the high average sound pressure level of $73.9 \mathrm{~dB}$. Therefore, we can indicate that several causes can produce high sound pressure levels generated by the vehicle fleet in our study area, as in E05 of this research work (Zeballos, 2019).

Analyzing the surveys made to the users in the stations worked, the Cronbach's Alpha statistic shows the instrument's reliability presents the tables and figures that support these results. Regarding noise sensitivity, in Figure 6, 53\% of people felt light or moderate noise; this indicates that, despite the high sound pressure obtained in the sampled stations, the human body quickly adapts to environmental conditions, which does not mean that the human body quickly adapts to environmental conditions the adverse effects are eliminated. Rodriguez found a similar result in 2015 in the urban center of Zaragoza (Spain), where $40.4 \%$ of students showed indifference when asked about the issue of noise from the vehicle fleet.

\section{CONCLUSIONS}

The application of Ordinance No. 310-2009-MDJM has a significant impact on noise pollution from the vehicle fleet in the district of Jesús María, 2020.

The application of Ordinance No. 310-2009-MDJM has a significant impact on noise pollution expressed in the noise map of the vehicle fleet in the district of Jesús María, 2020.

The application of Ordinance $\mathrm{N}^{\circ}$ 310-2009-MDJM has had a significant impact on noise pollution from private vehicles in the district of Jesús María, 2020. 
The application of Ordinance $\mathrm{N}^{\circ}$ 310-2009-MDJM has had a significant impact on noise pollution from public vehicles in the district of Jesús María, 2020.

The Municipality of Jesus Maria maintains the development of the process of surveillance and monitoring of environmental noise that has begun in late 2019, through the mayoral decree No. 008-2019-MDJM of April 29, 2019, so that it achieves the goal of maintaining the maximum permitted levels present in Ordinance No. 310-2009-MDJM, considering that with this research work has demonstrated the high degree of noise pollution by the motor vehicle fleet that exists in its geographical space.

\section{REFERENCES}

Alcántara-Malca, D. A., \& Esenarro, D. (2018). Low-cost remediation method to decrease the concentration of heavy metals in waters polluted by mining activity. Biotempo.

Alomoto, D. E. (2018). Lineamientos para el mejoramiento de la capacidad de respuesta, planificación y el ordenamiento territorial ante los efectos de lahares en caso de erupción del volcán Cotopaxi, en la parroquia rural San Francisco de Mulaló, cantó Latacunga [Tesis de maestría]. Pontificia Universidad Católica del Ecuador.

Alvarado, K., Esenarro, D., Rodriguez, C., y Vasquez, W. (2020). Lemna minor influence in the treatment of organic pollution of the industrial effluents. 3C Tecnología. Glosas de innovación aplicadas a la pyme, 9(3), 77-97. https://doi. org/10.17993/3ctecno/2020.v9n3e35.77-97

Amable, I., Méndez,J., Delgado, L., Acebo, F., De Armas, J., \& Rivero, M. L. (2017). Contaminación ambiental por ruido. Revista Medicina Electrónica, 39(3). http://www. revmedicaelectronica.sld.cu/index.php/rme/article/view/2305/3446

AMBIO. (2018). Acerca de nosotros. AMBIO Corporation. http://ambio.org.mx/manejointegral-del-territorio/ 
Bizkaia. (2018). Informe sobre ruido Ambiental y Salud. https://www.bizkaia.eus/home2/ archivos/DPTO2/Temas/Pdf/Ruido\%20Normativa/Informe_ruido_ambiental_ salud.pdf?hash $=4$ f8769cdbeab875aa77e74a23b25b7c5\&idioma $=\mathrm{CA}$

Delgadillo, M. G., \& Pérez,J. E. (2017). Evaluación de contaminación sonora vehicularen el centro de la ciudad de Tarapoto, San Martín. Revista de Investigación Ciencia, Tecnología y Desarrollo, 3(2). https://revistas.upeu.edu.pe/index.php/ri_ctd/article/view/654

EFE. (2018). La OMS recomienda limites a exposición al ruido por su impacto en la salud. Agencvia EFE. https://www.efe.com/efe/espana/sociedad/la-oms-recomienda-limites-aexposicion-al-ruido-por-su-impacto-en-salud/10004-3776158

Figueroa, F., Arteaga, W., Lopez, E., \& Lozano, E. (2018). Evaluación de contaminación de ruido en la intersección de las Avenidas Hoyos Rubio y firón Manuel Seoane en la ciudad de Cajamarca. Universidad Privada del Norte. https:/ / library.co/document/zw039dlyevaluacion-contaminacion-interseccion-avenidas-hoyos-manuel-seoane-cajamarca. html

González, P. (2019). El ruido también perjudica la salud. Revista EFE: Salud. https:/ /www. efesalud.com/ruido-perjudica-salud/

Gray, A. (2017). Estas son las ciudades con la peor contaminación acústica. World Economic Forum. https://es.weforum.org/agenda/2017/04/estas-son-las-ciudades-con-lapeor-contaminacion-acustica/

Hidalgo, M. N. (2017). Determinación del ruido ambiental nocturno y su efecto en la salud de los pobladores en la Av. Chimú - Zarate de San Fuan de Lurigancho, 2017 [Tesis]. Universidad César Vallejo. https://repositorio.ucv.edu.pe/bitstream/handle/20.500.12692/18681/ HIDALGO_RM..pdf? sequence $=1$ \&isAllowed $=\mathrm{y}$

Mamani, D. J. (2017). Valoración Económica de la Reducción del Ruido por Vehículos en el distrito de Ate en el Perído 2017 [Tesis]. Universidad César Vallejo. https:// repositorio.ucv.edu.pe/bitstream/handle/20.500.12692/6882/MAMANI-CDJ. pdf? sequence $=1$ \&isAllowed $=\mathrm{y}$ 
MDJM. (2019). Decreto de Alcaldía. https://www.munijesusmaria.gob.pe/pdf/ decretos/2019/decreto008-2019.pdf

Municipalidad de Jesus María. (2021). https://www.distrito.pe/distrito-jesus-maria. html

Ocas, A. (2018). La contaminación acústica del sector transporte y sus consecuencias en la salud de la población del Distrito de cajamarca 2011 - 2015 [Tesis]. Universidad Nacional de Cajamarca. https://repositorio.unc.edu.pe/bitstream/handle/UNG/1890/ T016_45726825_T.pdf? sequence $=1$ \&isAllowed $=\mathrm{y}$

Ordenanza No1965. (2016). Ordenanza Metropolitana Ciudad de Lima para Prevención y Control de la Contaminación sonora. https://sinia.minam.gob.pe/normas/ordenanzametropolitana-prevencion-control-contaminacion-sonora.

Reyes, A., Rodriguez, G., Pacheco, A., \& Esenarro, D. (2021). Implementing Model Applied to a Virtualized Data Center based on Open Source Projects. Test Engeeniering \& Management. http://www.testmagzine.biz/index.php/testmagzine/ article/view/5280

Rosales,J.(2017).Efectos de la contaminación sonora de losvehículos motorizados terrestres en los niveles de audición de los pobladores de la localidad de Santa Clara-Ate 2017 [Tesis de grado]. Universidad César Vallejo. http://repositorio.ucv.edu.pe/handle/20.500.12692/3604

Zevallos, M. (2019). Contaminación sonora y el efecto en el deterioro auditivo de los pacientes del policlinico municipal de San Fuan de Lurigancho - Lima [Tesis de maestría]. Universidad Nacional Federico Villareal. http://repositorio.unfvedu.pe/bitstream/handle/ UNFV/3572/ZEVALLOS\%20LEON\%20MAXIMO\%20-\%20MAESTRIA. pdf? sequence $=1$ \&isAllowed $=\mathrm{y}$ 